\title{
The Revival of Chineseness as a Cultural Identity in Malaysia
}

\author{
Saiful Anwar Matondang \\ Universitas Muslim Nusantara AW, Medan, Indonesia
}

\section{A. Introduction}

Malaysia Peninsula in British colonial power was a plural society (Furnivall, 1965,: Giordano, 2015) due to the massive immigrants from the Southern part of China and the India. The plural society then has been formed into the multicultural society (Mustafa Ishak, 1999; Shamsul AB, 2001; Matondang, 2016). A Malaysian plural society is showing how the Chinese as the second largest ethnic group in Malaysia interact with and adopt some elements of Malaysian culture. Considering the Malaysian Chinese that have a long history, the revival of ethnic awareness in current global context, there is a need to explore the process of multiculturalism in Malaysian society from colonial past and ethno-nationalism phases to the present situation. Chinese descendants or Peranakan in Malaysia have the making and remaking identity in an even process that creates the cultural identity of Malaysia.

A term of "Chineseness" or "ReChinezed" (Ang, 2011) as the way of getting reinvented the shared traditions and memories gives a new strategic to study a multicultural society of post colonial Malaysia. After the May 13, 1969 riots, the Malaysian Government launched the National Culture Policy, which favored the Ketuanan Melayu (Supremacy of Malay culture) as national identity. Malaysian people (natives) as Bumi Putera (the sons of the soil or Malaysian land) enjoyed the privilege in economic, culture and education under the Affirmative Action. In response to the National Cultural Policy, the Chinese culture underwent a new sociocultural process in Malaysia. The Chinese tried to reorganize the position of this second largest social group in adapting to the National Culture Policy, after it was implemented in 1971 (Tan, 2007 and 1990). The National Culture Policy creates the privilege position of Malay culture among ethnic groups in Malaysia (Lian, 2006). This policy shows not only a symbolic effort to represent the Malay culture as national culture, but also a reinvention of the values of Islam that might be applied for all ethnic groups. The National Culture Policy in 1973 implies the educational system in Malaysia the imposing of Bahasa (Malay language) as the medium of instruction at all educational levels. 
Adaptation to the government policy among the Chinese Peranakan of Malaysia shows the difference responses. Lee (2000) reports on how the Chinese felt under the new policy, describing the intercultural relationship in Malaysia in early 1970 as follows;

The state imposed increasing regulations and restrictions on their rights to stage public cultural performances or to acquire land to build Chinese schools and places of worship and burial, and it induced the Chinese to mobilize to defend and struggle for their cultural space and rights. The impact of the state cultural policies on the ethnic relations over the years depends on several factors. One factor is connected to what were the prevailing conceptions of Malay culture and the elements of the non-Malay ethnic cultures that could go into the national culture. Another factor has to do with the specific cultural policies formulated and the manner in which the Malay-dominated state had pursued those (Lee, 2000).

By imposing the National Culture Policy, the Malaysian government basically tried to avoid communal violence. That might come from the unrest -feeling of the Malays because of a long ignorance in colonial era; but in postcolonial period, they expected government prioritized the indigenous culture. On the other hand, as the process of National Culture Policy went on, after the Chinese reaction and the wave of cultural tension lasted a few years, the Chinese started to understand how to make a cultural adaptation with the new policy. Freedman (2001) found that "Malaysia's political apparatus reflects a desire to manage ethnic cleavages, not to ignore or subsume them" (Freedman, 2001: 415). Fortunately, Malays in terms of cultural context began to feel secure, and the Chinese acceptance of the subordination of Chinese sub-ethnic languages and cultures to Bahasa as national language in the reality of multicultural society in Malaysia Starting with a peaceful cultural strategy, after a lot of cultural dialogues provided by government and mediators, eventually Malaysia Chinese were given cultural space proportionally within public space together with other ethnic groups in Malaysia. 


\section{B. Theoretical Reviews.}

\section{Awareness of the Cultural Identity of Chinese in Malaysia}

Chinese cultural identity awareness (gongshi) was an important experience in the national building process of a multicultural society in the postcolonial Malaysia. A growing awareness of transnational Chinese culture in the globalizing Chinese community that interacted with new religious networks is increasing. It remakes the cultural identity of Chinese in transnational context since 1980. Chineseness as a potent cultural maker has been used in the remaking of identity in many forms of rituals and festivals in public spaces and social media. As a consequence, in adaptation to the ethno-national formation of Malaysia, the Chinese communities in Malaysia even found a cultural strategy to reclaim the Malaysian Chinese identity, especially in public spaces. Yen's research explores the Chinese cultural identity in Malaysia, which increased and accelerated in the 1970s. This research found a way of the Malaysian Chinese preserving the Chinese culture in response to the National Culture Policy of Malaysian government, which emphasizes the Malay culture as national identity. Yen also explains the process of creating Malaysian Chinese cultural identity under two influences (local and international elements) which occurred during one decade in Malaysia.

The Chinese, in the revival of ethnic identity, tried to create a new form of Malaysian Chinese cultural identity. The revival of Chinese culture in Malaysia was not only a matter of adopting the patterns of recommended cultural practices from the National Culture Policy, but it also had been creating a new hybrid culture among Chinese communities. Carstens explains that "from the late 1970s and throughout the 1980s, Chinese associations and Malaysian Chinese individuals engaged in an ongoing debate with government officials over the form and content of Malaysian national Culture, encouraging the government to recognize particular Chinese customs and practices as legitimate components of Malaysian National identity (Carstens, 2003: 326)". Malaysia saw the Malaysian Chinese experience during the process of cultural transformation from 1970 until 1980 within a harmonious ethnic frame on one side, and at the same time, it absorbed the Chinese transnational cosmopolitan identity. With regard to revival of Chinese cultural identity in Malaysia in terms of the reciprocal influences of government policy and transnational Chinese in Asia Pacific, the formation of culture identity of Malaysian Chinese challenges for us. As a consequence, a specific study of the resurgence of Malayness as an internal factor, along with the Chinese diaspora linkage of Asia Pacific rim as an external one, is needed. This paper provides a detailed explanation of the daily contacts and institutionalization of cultural identity based on the experiences of different ethnic groups. The resistance to an 
emerging Malayness and the transnational Chinese cultural ties to the formation of Chineseness in Malaysia hybridized the Chinese Malaysian into a new cosmopolitan culture, especially among the middle class society.

Uniquely, the Malaysianization of Chinese culture (Malai xiyahua) is not identical with that of Taiwan or Mainland China. The Malaysian Chinese established cultural organization and promoted Chinese cultural traditions like dragon, folk and lion dances; music, tea-drinking, poetry, painting, and Chinese cuisine blended with local elements (Yen:, 2002175). For example, the Malaysian "Laksa" (the Chinese noodle curry with Malay's flavor) became a culture identity.

A sociocultural process of the Chinese community in Malaysia proceeded to national identity; it constantly shows that the Chinese community had already gained the opportunity to reclaim its Chineseness. As the Chinese regained more spaces for their cultural symbols and practices in Malaysia, Yen's research reveals a Chinese culture revival process occurred in Malaysia. It was not only internal factor, but it also was clearly enhanced by globalization. An advanced communication system brought the revival of the Chinese culture, a process which enabled access to the cosmopolitan culture rising up from Chinese culture in the Asia pacific region.

The Chinese communities revived their great traditions by adopting local and foreign elements which grew a transformation process. The revival of Chinese culture in Malaysia started with a new identity which involved two-sided from 1970 to 1980; the creation of Chinese culture in Malaysia began with regaining the Straits Melaka Chinese tradition like glorifying "Datuk Kong Cult" " and combining with the external factor from Transnational Chinese or cosmopolitan identity of Chinese overseas outside Malaysia. Globalization and communication technology made the Malaysian Chinese possible to create a new culture. For instance, young educated Chinese started to use technology and media to represent the Chinese culture that combined the Chinese myths with modern myths. ${ }^{2}$

\section{Responding to Malaysian National Culture Policy}

\footnotetext{
${ }^{1}$ Datuk Kong Cult was a local Penang shrine that used by Chinese community based on the hybrid beliefs of the Chinese and an ancient Malay of supernatural of power in Penang which protected inhabitants. Since the revival of Chinese culture, the Chinese communities in 1980 modernized Datuk Kong shrine.

${ }^{2}$ Frequently, the Chinese Festivals in Malaysia were recast based on the ancient Chinese stories with a modern (Western) genre and music instruments.
} 
Although the Chinese communities in Malaysia are basically inclined to associate with various the sub-ethnic groups, the National Culture Policy of Malaysia solidified them in 1970. The Chinese communities in Malaysia felt that this policy tended to glorify the Malay culture and threaten the Chinese culture. The cultural pride of the Chinese made some Malaysian Chinese collectively oppose this policy. The Chinese associations, Halls, and Teachers Movement unified to show reactions, suggestions, and approaches to the government policy. The Chinese communities, for instance, approached the Malaysian opposition party, The Democratic Action Party (DAP), to sound their voice in politics.

At the same time, Dong Jiao Zong (The Chinese Teacher Movement) had shown educators' displeasure at the new requirements. The Chinese expected cultural policy would come at the expense of Chinese-language instruction. As guaranteed in the Constitution, to be educated in ethnic language or mother tongue, was regarded by the Malaysian Chinese as their right. Eventually, the Chinese channeled the institutionalized Chinese culture by approaching the ruling elites about appreciation for the Chinese culture in Malaysia (Freedman, 2002).

\section{Chinese Associations, Halls, and Teachers Movement}

Chineseness is reinvented in the associations and halls. Chinese solidarity increased in early 1970 until 1980, and continuity is found when the young generation connects the Chineseness with the present transnational situations. The Chinese reclaim their cultural identity when the government used the Malay culture of national identity. The Chinese communities from different sub-ethnic groups tried to represent the Chinese culture in Malaysia. The most important cultural movement of the Chinese came from educational institutions. As the strong feeling had increased, the well-known Chinese teachers' organization Dong Jiao Zong (DJZ) mobilized the Chinese communities to preserve Chinese culture through vernacular schools at the elementary level. DJZ used to gather frequently in the Hainanese Hall in Kuala Lumpur to obtain favor and write their petition to the government. Additionally, Malaysian Chinese established the United Chinese School Committees' Association (UCSCA) and the United Chinese School Teachers' Association (UCST). Collins (2006) described the language solution given to the Chinese by the government: "Mandarin is used in the Malaysian context to mean a spoken and written form of Chinese that is recognized by Chinese speakers in Malaysia as their common language or mother tongue. The English-language policy appeared to confirm the teachers' perception that the government had little interest in safeguarding Chinese ethnic identity as part of Malaysia's national identity" (Collins, 2006). The Chinese communities worked within associations and cultural movements to show their cultural identity must be 
preserved by Malaysians, as what Yen (2002) finds, the Malaysian Chinese established cultural organization and promoted Chinese culture traditions.

Despites the successful achievements of the Chinese associations, halls, and teachers' movement in reviving the Chinese culture in Malaysia, the Chinese in certain occasions disunited. For example, one of the Chinese Parties, which was in power with the ruling party (UMNO) alliance with National Front (NF), the Malaysian Chinese Associations (MCA) actually is not favored by the majority of Chinese communities. Some Chinese vote with the Democratic Action Party and Gerakan. The Chinese tend to avoid the political and racial issues. The Malaysian Chinese prefer to look at the function of shared culture to glorify the cultural identity.

The Chinese in Malaysia are separated politically. The Malaysian Chinese Association (MCA) joined the ruling party (UMNO); on the other hand, the Democratic Action Party (DAP) and Gerakan are in opposition side. The Chinese communities are sharing Chineseness culturally, but not politically. When the Democratic Action Party (DAP) with Merdeka Berhad (Enterprise) proposed a Mandarin-medium university, the Malaysian Chinese Association (MCA) was not interested in joining this project. The government rejected the establishment of the Merdeka University, and the High Court justified this rejection in 1981. The reason of government objection to the Merdeka University using Mandarin as the medium of instruction was that it was not as national or international languages recommended but only an ethnic language. This controversial proposal ended because the High Court supported the objection of the Minister of Education. This implied that vernacular schools were only permitted at the Primary level, not in higher education. Bahasa Melayu and English, not ethnic languages, are used as the medium of instruction in higher education. On one side, Chinese symbols and written script are regarded as high culture among the Malaysian Chinese, but the government policy regarded Mandarin is only an ethnic language. The Malaysian government considered Bahasa Melayu as national identity, and importantly to be the main of the medium of instruction and English as optional. The Chinese communities found that Malays still viewed the Chinese symbols with suspicion. As the cultural process continued, the Malaysian Chinese finally realized this and sent their children to Taiwan or Hong Kong when they wanted the children to learn Mandarin and Chinese culture. 
4. The Chinese Culture and the Chinese Political Parties (DAP, Gerakan, MCA)

On a micro level, the Chinese individually come into contact with other groups in Malaysia. But on macro or political levels, the Chinese go about strategically relating with the Chinese-based political parties. The Malaysian Chinese Association (MCA) is a National Front Alliance of the ruling party, UMNO, as soon as Malaysia got her independence. The Democratic Action Party (DAP) and Gerakan are new opposition parties. These two parties were established because some Chinese felt MCA did not represent poor Chinese. Eventually, as these two parties appealed to some Chinese in Malaysia, they have already been supported by middle class Chinese.

In the case of preserving the Chinese culture, all the political parties (DAP, Gerakan, and MCA) were approached by the Chinese associations and Teachers' Movement. Collins (2006: 306) explains that Teacher movements like the Dong Jiao Zong (DJZ) also sought political parties' help in getting government attention for preserving the Chinese culture in Malaysia. Collins elaborates:

In this sense, the DJZ has attempted to operate as an insider pressure group. However, working with the MCA and Gerakan in order to influence government policy has been a largely frustrating experience for the DJZ. The MCA leadership has found itself caught in the dilemma of wanting to support the Chinese educationalists, both because it is sympathetic to their concerns and because it does not want to alienate Chinese voters, while also wanting to support its alliance partner, $U M N O$. The nature of Malaysia's coalition government, where $U M N O$ is always the dominant partner, militates against the DJZ because the MCA, when forced to choose, has sided with UMNO (Collin, 2006:3006)

\section{An Ethnohistory Approach in Ethnographic Method}

This research applied an ethnohistory approach in the ethnographic research. Ethnohistory combines the historical documents tracing mode and the present situation of ethnicity based on an observation in the society (Sturtevant, 1966 and Andaya, 2008). Thinking of the colonial classification of ethnic groups in Malaysia Peninsula, the conceptions of community (Stockwell, 1998) is highly considered in this method. Zbigniew Libera shows the importance of historical data in ethnography, Libera says:"By considering people as subjects of history, whose 
actions are determined by cultural rules and texts, cultural semiotics presents histories (in the same way as ethnography presents cultures) somehow from interior, in a micro scale (ethnographically)" (Libera, 2011: 601).

An observation was conducted in Georgetown and Kuala Lumpur Malaysia around two months in 2014 during the welcoming and enacting of Spring Season Celebration of Chinese. The subject of observation was the collective cultural behavior of the Chinese Peranakans when they have the rituals, festivals, culinary shows exhibited in public spaces, and social media interactions (in English versions) were followed, too. In the fieldwork in 2014, there was a celebration of the Wooden Horse Chinese New Year (Imlek) that Chinese Peranakan had observance. The collection of myths and shared memories from Chinese Peranakan were reconstructed in the New Year and this model reshapes the meaning of Chineseness. Observation reframed the cultural identity of Chinese Peranakan in Malaysia creates the mosaic of multicultural society in a more colorful formation.

\section{Data Analysis and Interpretation}

\section{Hybridizing Chinese Culture Identity}

Hybrid culture process appears when the Chinese descendants of Malaysia adapt to ethno-national and transnational links of Chinese since 1980 until now. Following the idea of Malaysia at the end of 1980 became a battle field of multiethnic culture revival, the hybrid culture appearance as the collective way of getting adapted to a new policy of government and a transnational link of Chinese at global level becomes the core of the analysis of this discussion. As has been outlined in the history of Malaysia's Vision 2020, a grand narrative of modernity in an attempt to create new Malay; we could also view Malaysia as an industrialized nation-state. Giordano (2015) argues that " the deep transformations in the social structure, which significantly altered the plural society inherited from British colonial rule, have not destroyed tolerant yet not trouble -free co-existence between ethnic groups" (Giordano, 2015: 244). The Chinese cultural movement proponents' efforts linked with the Malaysian policies and the cultural productions. Their movement involved not only policy but also the multilayered struggles over globalization. For instance, as a global phenomenon widely spread, the overseas Chinese associations (kinship and native places) were transformed into global networks which expanded economic and cultural ties (Ang, 2001: 78). Len Ang's observation about the Chinese diaspora in Asia-Pacific shows that the globalized relationship among the Chinese overseas crosses the national boundaries. Whereas 
Donald Nonini argues that the interplay of local-cosmopolitan and global link connect Chinese businessmen in Southeast Asia to local elites and modern finance sources (Nonini, 1997: 203-207), Len Ang sees more than economic relations: she emphasizes a transnational cultural identity of many ethnic Chinese. When the prosperity of the Chinese community was better because of economic growth, the Malaysian Chinese built communal buildings and claimed "social honor through extravagant, rivalries feasts and festival displays (DeBernadi, 2004: 220)."

In the context of Malaysia, global paradox was followed by the assertion of cultural identity. There was a resurgence of the religious values and cultural identity in Malaysia. The Malaysian Chinese, regardless of their beliefs (Buddhist, Christian, or non- believers), glorify their cultural identity in a great variety of modern manners. Yen (2002), for example, takes the 1998 Niansi Jielinggu (Festivals of Twenty-Four Drums) as one of the examples of Chinese hybrid culture in Malaysia. This festival was inspired by the farmer's calendar in terms of seasons in ancient China. The Malaysia Twenty-Four Festivals Drum represents agricultural seasons of the Chinese calendar. Each season - winter, spring, summer, and fallis painted in calligraphy on each drum. . The winter and spring seasons are the primary icons, which are further divided into six secondary seasons. In the fieldwork, in the celebration of 2014 Chinese New Year in Georgetown of Malaysia, the 15 days of feasts showed the hybrid rituals and festivals such as Jade Emperor Offering, Cap Go Meh in front of Kuan Yin (Mercy Goddess Temple), Ching ngay acrobats, lion and dragon dances, staging various liturgy dramas in public spaces.

The Malaysian Chinese revived the Chinese traditions such as Confucianism, or ancestral culture; the Malaysian Chinese brought back their culture in a modern setting. "The defense of identity and values also has been as issue for the Chinese of Penang who have made their institutions and practices more than once in the structure of conjunction with the new global structures of modernity" (DeBernadi, 2004: 220-221). The hybrid culture which was created by Malaysian Chinese took a sociocultural approach in interacting within Malaysian environment and globalization. The process occurred gradually in the Chinese communities. It shaped a realistic cultural identity in a fast-pace global culture. A primordial model that emphasized the Chinese brotherhood was combined with a situational model. The Chinese communities interacted with both models. Within a situational model, the Malaysian Chinese found that a strategic adaptation in the global economy brought a new hybrid culture. It brought them to the current popular transnational culture, or cosmopolitan Chinese cultural identity. 
A long sociocultural process of Chinese awareness was increased the Chinese culture activism in modern Malaysia; it already brought a transnational identity, or cosmopolitan model. Working in both the environments of Malaysian culture and global culture clarifies the puzzles circling around Malaysian Chinese. The reconciled of the Chinese culture with two powers, regulation of Malaysian government and global culture transformed the Malaysian Chinese identity from a primordial model to situational one, like a cosmopolitan cultural formation. The Malaysian Chinese interaction with the Chinese overseas created a hybrid culture accepted by all ethnic groups in Malaysia.

\section{Interacting with Asia Pacific Chinese Culture Identity}

Transnational interaction makes the ethnic formation in modern technology more rapidly changes in response to national and global situations. It finds the interconnection of ethnic remaking in a new phase; a more widen scope or beyond national border. It also enhances the ethnic power (Castells, 2010) in Wallerstain's World system. The Asia Pacific Rim was experiencing a very rapid economic growth in 1980. The Chinese social and commercial organizations were integrated with transnational connections. Many researchers believe that interaction among the four mini dragons (Hong Kong, Taiwan, South Korea, and Singapore) demonstrated the revival of Confucianism in the global economy. Chinese capitalism, along with economic growth, not only increased the income per capita, but it introduced Chinese cultural identity outside of Mainland China (PRC). Ong and Nonini's book Ungrounded Empires elaborates on the Chinese culture of overseas Chinese from colorful perspectives. Some overseas Chinese participate to build a new, imaginative Chinese state. This spectacular economic growth helped the Chinese reclaim the Chinese culture. The idea of perceiving Chinese identity as a superior civilization consequently motivated the Chinese overseas to mythologize the Chinese culture in a modern manner.

\subsection{Rediscovery of Confucianism in the New Industrial Countries (NICs)}

Rediscovery of Confucianism in Hong Kong and Taiwan-because of economic opportunity and communication technology-influenced the Chinese overseas in 1980. The Chinese transnational mass media, such as popular culture from Hong Kong, spread widely in Southeast Asia. Malaysia, as with other South East Asian countries' experience, interacted with the Hong Kong mass media which highlighted and illuminated transnational shared culture. When the Chinese communities in Malaysia needed a formation of Chinese cultural identity in responding to government policy, the Hong Kong mass media and cultural 
representation of cosmopolitan or urban society brought a new inspiration for Malaysian Chinese.

Malaysian Chinese communities, with the advancement of communication technology since 1980, have had the opportunity to get in touch with Asia Pacific countries. By watching television programs and VCD, the Chinese overseas communities in Malaysia have access to the Chinese culture as cultural productions. Interestingly, Carstens's (2003) ethnographic study on the transnational popular culture of Chinese in the Hakka-Speaking Chinese community in Pulai Kelantan, Malaysia showed the Malaysian Chinese in 1984 were interested in movies from Hong Kong and Taiwan. As they began to receive the Chinese movies on VHS in 1984, the Malaysian Chinese rented videos to watch films from Hong Kong and Taiwan. Carsten's (2003) study shows that the Malaysian Chinese community prefers the Hong Kong movies over Malaysian ones. By comparing the Chinese community from four different states in Malaysia; Kelantan, Ipoh, Penang, and Johor, Carsten's research reveals that the Cantonese movies in Ipoh were better appreciated than those of Mandarin. In addition, the Malaysian Chinese felt that the British colonial experience was similar to that of Hong Kong.

The fieldwork on the 2014 Chinese celebrations in Georgetown showed that the Chinese songs, liturgy dramas, festivals, and food for feast were the objects of this ethnography. Observing the locations of New Year Celebrations in Kapitan Keling Street, Pangkalan Weld/Clan of Jetty, shopping malls gave the symbolic meaning of the restoration of Chinese culture with some changes. The celebration symbolizes the revival of ethnic Chinese awareness in Malaysia as cultural identity within a multicultural society. The revival does not relate with the Mainland China political ideology, but it is more the embedded of cultural elements such as ancient tradition reconstructions neither structural change.

\subsection{Kinship and business networks in Asia Pacific}

The Malaysian Chinese refer to blood (phenotypical) and bloodline (genotypical), as well as cultural attributes, as a marker of ethnic identity. The Malaysian Chinese tend maintain the Chineseness of their family members by giving Chinese names to their children. They also use surnames as an identity maker. The Chinese in Malaysia also participate in festivals such as Qing Ming and Bak Chang When Tong conducted a research on the bloodline as an identity maker among Chinese communities in Malaysia; he found that "almost all informants mention phenoltypical characteristics and blood as the basis for ethnic identification" (2006: 101). 
Ancestor worship is a key religious belief and practice of the Chinese, as the tablets are inscribed with the title and name of the deceased, dates of birth and death, and the names of sons. For economic benefits, the Chinese were expected not only to preserve xiao (filial piety), but also to maintain business networks (guanxi). A strong relation within the Chinese Asia Pacific networks in economic and financial sectors of the Chinese overseas influenced the growing businesses of Malaysia. The Chinese businessmen in Malaysia worked not only with Malaysian elites, but also with Asia Pacific business networks. Hirschman's (1986) research on the Chinese networks in Malaysia concludes:

Almost every business must depend upon the cooperation of other businesses for sources of supply, credit, transport, and market access. Without a strong base of kinship networks to provide these supporting services, entry into the entrepreneurial world was probably quite precarious. Neither the colonial government nor the Malay aristocracy was motivated to intervene. As the colonial administration developed in the twentieth century, the few educated Malays could find alternative employment in the junior ranks of the civil service or in the teaching profession. These positions offered low pay, but did give job security and high status in the highly status-oriented colonial society. (Hirschman, 1986: 352)

hese ancestral values and social networks provided the Malaysian Chinese with a strong tie to Asia Pacific business and cultural evolution among the Chinese communities. The Malaysian Chinese, in maintaining their businesses, believe in hard work and tenacity, as those factors are regarded as inherited Chinese cultural traditions. At the same time, transnational identity, already boosted by popular culture from Hong Kong and Taiwan since 1980, was increasing in Malaysia. The cosmopolitan movies and fashion from Hong Kong greatly influenced the younger generation in Malaysia. The 2014 celebration of New Year in the downtown of Kuala Lumpur was very colorful. The number of cultural attractions was found in many places. The city was surrounded by the lampions and ornaments that showed that spring tradition of Chinese was being exhibited in cheerful.

\section{Conclusion}

Thi research paper concludes that two important moments that make the revival of Chinese culture becomes a culture identity in multicultural society of Malaysia today. The Malaysian Chinese revived the Chinese cultural identity since 1970 and 
it was taking a transformation process which resulted in a cosmopolitan identity by the end of 1980. Those moments create a Chinese culture in Malaysia in a welldesigned manner; by interacting with internal pressure and external Resinicization (Ang, 2011) of transnational identity, the Malaysian Chinese created a new hybrid culture after experiencing a long sociocultural process and cultural dialogues in Malaysia. Starting from reclaiming the Chinese great traditions as a cultural identity, the Chinese communities in Malaysia already created a hybrid culture in cosmopolitan setting that led the cultural identity formation in the multicultural society.

The second conclusion is that the remaking of cultural identity in art performances of Chinese makes Malaysian multicultural society richer and plural in a new shape. With the Chinese cultural identity in Malaysia, the Chinese communities, especially from middle-class society, reinvented Chinese values and traditions. It was found that it had attractions not only to Malaysian Chinese, but also to all Malaysians and tourists. The contribution of the Chinese culture for national culture of Malaysia could be viewed from the meanings of the Malaysian cosmopolitan identity in national and regional levels. The Chinese enactments of ritual and festival, such as the international lion and dragon dances have already become transnational events and watched by all ethnic groups in Malaysia as natural feature of multicultural society.

\section{References and notes:}

1. Andaya, Leonard Y. (2008). Leaves of the Same Tree: Ethnicity and Trade in the Straits of Melaka, Honolulu: University of Hawai'i Press

2. Ang, Ien. (2001). On not speaking Chinese Living between Asia and the West, New York: Routledge.

3. DeBernadi, Jean. (2004). Rites of Belonging, California: Stanford.

4. Carstens, Sharon A. (2003).Constructing transnational identities? Mass media and the Malaysian Chinese. Ethnic and Racial Studies, 26, 2, March.

5. Castells, M. (2010). The Power of Identity, Second edition . Sussex UK: WilleyBlackwell.

6. Collins, Allan, Chinese Educationalists in Malaysia: Defenders of Chinese Identity. (2006). Asian Survey, 46, 2 March/April.

7. Freedman, Amy L. (2001).The Effect of Government Policy and Institutions on Chinese Overseas Acculturation: The Case of Malaysia, Modern Asian Studies, 35, 2 , May.

8. Giordano,Christian .(20015). Power, Legitimacy, Historical Legacies, A Disenchanted Political Anthtopology, Lit Verlag: Zurich

9. Furnivall, S. (1965). Colonial Policy and Practice. Cambridge: Cambridge University Press. 
10. Hirschman, Charles. (1986). The Making of Race in Colonial Malaya: Political Economy and Racial Ideology, Sociological Forum, 1, 2, spring.

11. Jomo, K S. (1997). A specific idiom of Chinese Capitalism in Southeast Asia: SinoMalaysia Capital Accumulation in the face of State Hostility, in Daniel Chirot and Anthony Reid, Chinese and Jews in the modern Transformation of Southeast Asia and Central Europe, Seattle: University of Washington Press.

12. Lee Hock Guan. (2000) Ethnic Relations in Peninsular Malaysia: The Cultural and Economic Dimensions, Singapore Institute of Southeast Asian Studies, August.

13. Lian, Kwen Fee. (2006).Race, Ethnicity and the state in Malaysia and Singapore, Leiden: Koninklijke Brill NV.

14. Libera, Zbigniew. (2011). History and Culture Problem of Cultural Anthropology and Historical Anthropology, Anthropos, Vol. 106/1.

15. Matondang, Saiful Anwar. (2016). Celebrating the Local Traditions for Global Heritage Tourism, International Humanities Studies, Vol. 1/3 - OAJI and EBSCOHOST

16. Mustafa Bin Ishak, Mohammed. (1999). From Plural Society to Bangsa Malaysia: Ethnicity and Nationalism in the Politics of Nation Building in Malaysia, Unpublished PhD Thesis, The University of Leeds.

17. Ong, Aihwa and Donald Nonini. (1997). Ungrounded Empires: The Cultural Politics of Modern Chinese Transnationalism, New York: Routledge.

18. Shamsul, AB. (2001). Transformation of Malaysia Pluralism. In Robert W Hefner, The Politics of Multiculturalism Pluralism and Citizenship in Malaysia, Singapore, and Indonesia, Honolulu: University of Hawai'i Press.

19. Stockwell, A. J. (1998). Conceptions of Community in Colonial Southeast Asia. Transactions of the Royal Historical Society, Sixth Series, 8.

20. Sturtevant, William C. (1966). Anthropology, History, and Ethnohistory. Ethnohistory 13(1/2) 1-51.

21. Tan, Sooi Beng. (2007). The Lion Dances to the Fore: Articulating Chinese Identities in Penang and Medan, in Y. Terada ed. Authenticity and Cultural Identity, Senri Ethnological Reports 65: 63-78

22. Tan, Sooi Beng. (1990, Winter) The Performing Arts in Malaysia: State and Society, Asian Music, xxi, (1), 136-150

23. Tong, Cheek King.(2006) The Chinese in contemporary Malaysia, in Lian Kwen Fee, Race, Ethnicity and the state in Malaysia and Singapore, Leiden: Koninklijke Brill NV.

24. Yen, Ching-Hwa.(2002).The ethnic Chinese in East and Southeast Asia, Singapore: Times Academic Press. 


\title{
Summary
}

\section{The Revival of Chineseness as a Cultural Identity in Malaysia}

\author{
Saiful Anwar Matondang \\ Universitas Muslim Nusantara AW, Medan, Indonesia
}

The revival of ethnic culture in the current globalizing world challenges the anthropologists and sociologists to study the multicultural societies. This phenomenon appears in urban areas of multicultural cities and it makes the ethnic background awareness lead to be a cultural identity remaking. With an ethnohistory approach and ethnographic fieldwork in 2014, this paper provides the cultural identity making and remaking process of Chineseness in Malaysia since 1970. Chineseness has contextualized the cultural process of cultural plurality to a complexity of the multiculturalism in Malaysian society. This research paper presents a history of social process that resulted in the Chinese culture identity revived in Malaysia after the May 13, 1969 riots, and analyzes two important factors; they are Government Policy and Transnational Linkage of Chinese, shaped and illuminated the Chinese cultural identity in Malaysia. The government policy upholds the Ketuanan Melayu (Supremacy of Malay culture with affirmative action) and the Chinese descendants or Peranakan in adapting national situation, then they sought their shared traditions and memories as well as link them to transnational of Chinese culture in Asia Pacific region. The fieldwork data of 2014 show that multicultural society in Malaysia allows the Malaysia Chinese to enact their rituals, festivals, culinary shows and cultural attractions in public spaces and social media with a revival mode in which the reconstruction of ethnic identity represented as cultural productions of multicultural society.

Key words: Revival of Chineseness, plural society, multicultural society, Malaysia, cultural identity 